\title{
MALAYSIA AND THE SOUTH-SOUTH COOPERATION: REFLECTIONS ON THE MALAYSIAN TECHNICAL COOPERATION PROGRAMME
}

\author{
Nazariah Osman* \& Muhammad Muda \\ ( First author) \\ School of International Studies \\ Universiti Utara Malaysia \\ (nazariah@uum.edu.my; mmuda@uum.edu.my) \\ Doi: https://doi.org/10.22452/ jati.sp2018no1.5
}

\section{Abstract}

Malaysia's commitment to championing the interests of the developing countries took center stage in the nation's foreign policy. The Mahathir's Administration (1981-2003), in particular, had consistently championed their concerns and aspirations to the extent that the Malaysian Premier was regarded as the developing nations' hero. He was the voice of conscience in articulating the plight and challenges facing the developing world. Since then, over the last three decades, Malaysia emerged as an active player in promoting self-reliance of the developing countries through fostering partnership among them, as well as consistently and at times vocally expressing their agenda internationally. As can be seen, Malaysia's major initiative in assisting the developing countries through the South-South Cooperation has resulted in the establishment of the Malaysian Technical Cooperation Program (MTCP) with its main objective is to achieve sustainable economic and social development among them. The programme which reached its zenith during the premiership of Mahathir reflected Malaysia's commitment to the principle of equality and mutual benefit through South-South Cooperation and of her wish to move from a donor-recipient relationship to one of partnership in development. On top of that, the 'Smart Partnership' principle was incorporated in all MTCP programmes with a view to enhancing their value. In this respect, a so-called 'reciprocation' of technical expertise was particularly encouraged in areas where relevant expertise would be better developed in the participating countries. Through this two-way exchange of experiences and knowledge, Malaysia also benefited by learning from the collective wisdom of 
other developing countries. As a result, such bilateral exchanges will spawn a 'win-win situation' for all parties. To date, Malaysia has allocated some USD200 million (RM880 million) to this programme with 29,000 beneficiaries from 143 developing countries. Speaking at a roundtable meeting for the South-South Cooperation nations at the $70^{\text {th }}$ Session of the United Nations General assembly, Prime Minister Datuk Seri Najib Razak gave his assurance that Malaysia would continue to champion the developing nations' interests even though Malaysia is still gearing toward becoming a fully developed nation by 2020. To sum up, this paper examines Malaysia's strong commitment to the South-South cooperation and development as reflected in the MTCP programme. By doing so, Malaysia will be known and remembered for its dedication to assisting fellow developing nations that are too keen to emulate Malaysia's socio-economic success.

Keywords: Malaysian Technical Cooperation (MTCP), South-South cooperation, smartpartnership

\section{Introduction}

Malaysia's commitment in championing the interests of the developing nations became prominent in a number of international inter-governmental organizations, such as the Association of South-East Asian Nations (ASEAN), the Organization of Islamic Conference (OIC), the Non-Aligned Movement and the Commonwealth especially during the Mahathir Administration (1981-2003). This trajectory took a prominent tool in Malaysia's foreign policy. Under Mahathir, Malaysia consistently championed their concerns and aspirations with the Prime Minister being regarded as the 'voice' of the developing nations'. Dr. Mahathir was seen actively engaged in addressing and criticizing the North-South divide and the existing developmental gap between the rich and less developed nations and the imposition of Western life style and values on nations at various international forums. Since then, over the last three decades, Malaysia has emerged as a key player in defending and supporting the standpoint of developing countries through fostering partnership among them, as well as consistently and at times vocally expressing their agenda internationally (Institute of Strategic Management Studies [ISIS], 2011).

Malaysia's major initiative in assisting developing countries through a concept of South-South Cooperation was manifested in the establishment of the Malaysian Technical Cooperation Programme (MTCP), ostensibly established to achieve sustainable economic and social development among the developing 
countries. A closer inspection of the programme suggests that Mahathir believed that although Malaysia had in the past relied on technical, development and financial assistance from several developed countries to hasten the pace of its economic development, Malaysia, in turn, had launched its technical assistance programme targeted at developing countries which were less fortunate than she is. Undoubtedly, the MTCP revealed Malaysia's commitment to the principle of equality and mutual benefit through the concept of South-South Cooperation and its wish to move from a donor-recipient relationship to one of partnership in development and through the years, MTCP has been able to not only render its services, but also expand such from the six South Asian nations to over 130 countries which are mostly developing. These are in line with the training programmes of cooperation that include educational grant/scholarship provisions, specialized training, study visits/hands-on induction and attachments within Malaysia, rendering consultative services, and special assistance to other states in the strategic areas such as special projects, equipment procurements (Economic Planning Unit, 2008, pp. iii, xv). The Malaysian government has especially under Mahathir, additionally committed huge resources in funding the MTCP. It has also given special attention to the OIC member countries in the area of science and technology thereby building their research and researchers capabilities. In one aspect, the MTCP has special education and training programmes with over 145 short term courses under 46 Agencies and various departments engaged for special purposes.

Further, in 1995 the Langkawi International Dialogue (LID), again a brainchild of Mahathir, was launched. The Dialogue, which offers networking capacities by specifically promoting the pooling of technology for development, also provides an open platform for sharing experiences, and exploring new ideas in national development, and understanding new global issues for all participating countries.

The 'Smart Partnership' principle was incorporated in all Malaysia's South-South Cooperation initiatives to enhancing their value. In this respect, a so-called 'reciprocation' of technical expertise was particularly encouraged in areas where relevant expertise is better developed in the participating countries. Through this two-way exchange of experiences and knowledge, Malaysia can also benefit by learning from the collective wisdom of other developing countries. In recognition of the roles of Malaysia in promoting the South-South Cooperation cause, the United Nations Education Scientific and Cultural Organisation (UNESCO) in the year 2008 established an international Centre for the International Science, Technology and Innovation Centre (ISTIC). As a result, such bilateral exchanges were expected to spawn a 'win-win situation' for all 
parties. As Mahathir Mohamad (2011) notes in his memoirs, 'a doctor in the House', the MTCP is 'not inequality and manipulation ... over the years we have spent millions of ringgit on this programme, which helped us make friends around the world'. To date, Malaysia has allocated some USD200 million (RM880 million) to this programme which has benefitted 29,000 participants from 143 developing countries (Economic Planning Unit, 2008, p. xv). Speaking at a roundtable meeting for the South-South Cooperation nations at the $70^{\text {th }}$ Session of the United Nations General assembly held in 2017, the then Prime Minister Datuk Seri Najib Razak gave his assurance that Malaysia would continue to champion the developing nations' interests even though Malaysia is gearing toward becoming a fully developed nation. This paper will examine Malaysia's strong commitment to two key policy initiatives or programmes targeted at assisting fellow developing nations in their quest to emulate Malaysia's success story of sustainable development. By doing so, Malaysia will be known and remembered for its commitment to the developing world.

In another important initiative, Malaysia also promoted and subsequently has played a leading part in the Summit Level Group for SouthSouth Cooperation and consultation often conveniently abbreviated as G-15 in which membership has now expanded to 18 (The G-15 member countries: Algeria, Argentina, Brazil, Egypt, Indonesia, India, Jamaica, Malaysia, Mexico, Nigeria, Peru, Senegal, Venezuela, Zimbabwe, Kenya, Iran, Sri Lanka and Chile). It owes its origin to the statement issued in May 1986 in Kuala Lumpur at the conference organized by the Third World Foundation and the Malaysian Institute for Strategic and International Studies (ISIS). The statement recommended that it was both necessary and urgent for the South to reappraise its position and chart out a path for the future. To this end, it proposed the establishment of an independent commission of the South on developmental issues. The then Prime Minister, Dr. Mahathir Mohamad, raised this subject at the $7^{\text {th }}$ Summit of the Non-Aligned Movement (NAM) in Harare, Zimbabwe in September 1986, and the Group of 15 countries was officially launched at the $8^{\text {th }}$ NAM Summit in Belgrade, Yugoslavia in 1989.

The G-15 is essentially a working group selected from the NAM and G-77 countries to act as a catalyst to foster and generate wider South-South Cooperation in economic and trade as well as technical cooperation. The G-15 is also to help form a common stand on behalf of the Third World at various international conferences. With growing protectionism in the North and economic/technical assistance increasingly 'tied' up by political conditions, in particular, good governance and democracy, it could well be that Malaysia and other participating countries will want to place greater reliance on the South in 
the future. To enhance South-South Cooperation, it was thought necessary that member countries, as Mahathir Mohamad emphasized, "[W]e must think South. We must be proud of our South tradition and institutions. We must have confidence in ourselves. As a group, we can contribute to our national resilience through collective efforts". To help cement the solidarity and cooperation, Malaysia also extended its MTCP assistance to the G-15 countries (New Straits Times, 1992).

Malaysia's increasing involvement in global affairs, especially in the developing world and, especially under Mahathir, is a manifestation of a remarkable transformation of the country's economic fortunes over the past three decades. Although as a middle income country moving towards an advanced country status in the year 2020, Malaysia continues to present itself as a developing country, at least to developing countries, to underline the convergence of interests between Malaysia (one of the most successful developing countries) and the rest of the developing world. Perhaps Malaysia's interest in strengthening bilateral diplomacy with developing countries via foreign assistance such as MTCP is partly driven by its desire to present itself as a model state that will inspire other developing countries to follow suit. In essence, Malaysia's vastly increased involvement in global affairs since Tun Dr. Mahathir Mohamad's time is part of a more active international strategy to spread Malaysia's influence globally. By offering aid with no political strings or conditions, Malaysia has presented an attractive option to conditional Western foreign assistance, and in the process has gained valuable diplomatic prominence and influence to project her international interests. This study focuses on the motives of an emerging donor as opposed to that of traditional donors who are mostly advanced economies. Malaysia as an emerging donor provides an exciting frame of reference for foreign assistance, hence, examining this issue in Malaysia's interest. As indicated earlier, Malaysia has shown its commitment towards the implementation of foreign assistance to recipients through the MTCP and its corollary the Smart Partnership policy.

\section{Theoretical/Conceptual Framework}

Foreign assistance has been studied from various theoretical constructs (Lancaster, 2006). For the Purpose of this study, the constructivist approach offers a better understanding of the motives of Malaysia in its development assistance programme towards the developing countries. The Constructivist Approach comprehensively explains the reasons behind development assistance and perceptions as it seeks to understand how these donors choose their interests 
and preferences. As noted by Ruggie (1998), constructivism focuses on the constitutive role of norms, identities or shared understanding of individual decision makers and state actors (Ruggie, 1998). As such, constructivists perceive that the identity of the state determines its interests and actions in international affairs (Wendt, 1992). It can, therefore, be argued that Malaysian identity as a developing country and the emerging donor is the basis of its interests to assist fellow and less fortunate developing countries from Africa, Asia, Eastern Europe and Latin America as reflected in the manner by which the MTCP is organized and being implemented. In this respect, the constructivist approach helps us to comprehend how states choose their interests and preferences in issues such as foreign aid. Interestingly, the constructivist paradigm challenges conventional wisdom propagated by rationalist discourses, namely realism and liberalism, which focus on strategic questions such as how states pursue their foreign policy goals, including the calculate costs and benefits of different actions. As can be seen, the constructivist approach can provide a broader explanation of the expression of a norm that has evolved in the relations between and among states through their understanding that rich countries should provide assistance to poor ones to help the latter uplift the quality of the lives of their peoples (Lancaster, 2006). The constructivist approach as used in this study shapes Malaysia's motives in the leadership, commitment and rendering of development assistance to her contemporaries and other developing countries.

\section{Background}

The MTCP was officially launched on 7 September 1980 as the Malaysian Technical Assistance Programme (MTAP) during the time of Tun Hussein Onn Prime Minister Mahathir Mohamad's predecessor - at the New Delhi Second Commonwealth Heads of Government Regional Meeting (CHOGRM) to signify Malaysia's commitment to South-South Cooperation, and in particular to Technical Cooperation among Developing Countries (TCDC). The Summit acknowledged the need to make special steps to build up relations with small states, particularly the island states, in order to improve the development of these countries. There was common agreement at the Summit that CHOGRM would be a meaningful and worthwhile if it concentrated more on regional economic and functional cooperation. Tun Hussein made a constructive contribution at this meeting. He told the meeting that Malaysia had received assistance and cooperation from many countries both in the Commonwealth and outside of it. The assistance and cooperation gave to Malaysia since independence had enabled it to develop at a much faster rate. It was this 
experience that made Malaysia ever ready to participate in any cooperative efforts, initially providing modest aid to newly - independent and developing states in Asia, Africa and the Pacific. Although Malaysia's resources were limited, it was prepared to provide assistance to other countries in areas where it had the experience and expertise.

This spirit of partnership and cooperation and the shift from a donorrecipient relationship was underlined the following year, 1983, when the name of the program was changed to the MTCP. Although this may have been ambitious, Malaysia strongly believed that this was the best mode of developmental assistance programme. Hazri and Tang (2011) observe that what made MTCP such a distinguished and unique Malaysian assistance programme is that it was underpinned by the principles of "demand driven" and "untied aid". Unlike conventional foreign assistance programmes which are often linked to donor values and priorities, 'MTCP strives to represent a neutral development approach through partnerships'. The Joint Study on Effective Technical Cooperation for Capacity Development: Malaysia Country Case Study (2008) highlights that the MTCP was part of the strategy and commitment of the Government to promote TCDC, strengthen bilateral, regional and sub-regional cooperation, and nurture collective self-reliance among developing nations'.

Moreover, The Findings of the Study on the Benefits and Impact of the MTCP by the Economic Planning Unit of the Prime Minister's Department of Malaysia (2002) suggests that the 'Smart Partnership' principle was incorporated in all MTCP programmes with a view to enhancing their value. As indicated earlier, Mahathir in his memoirs viewed the programme as gearing towards making friends around the world for Malaysia. The Premier also revealed that he initiated the MTCP in response to demands from the developing countries which had long been interested in sharing Malaysia's development experience, specifically as regards to foreign direct investments, government administration, the diplomatic service and the production-sharing agreements of Petroleum Nasional Berhad (PETRONAS) with the major international oil companies.

As far as its objectives are concerned, it is vital to state that the MTCP has two types of objectives, those which are stated and those which are unstated.

\section{Stated Objectives:}

- To share development experiences with other countries.

- To strengthen bilateral relations between Malaysia and other developing countries.

- To promote South-South Cooperation.

\section{Unstated objectives:}


- To support the achievement of Malaysia's political and economic interests at the international level.

- To enhance Malaysia's image as an important contributing member of the international order.

With regard to the implementation strategy, the participating countries in the technical cooperation were identified and prioritized according to three major considerations:

\section{i. Political}

Countries which Malaysia had friendly diplomatic relations and political interest were targeted for enhanced bilateral relations through development cooperation;

\section{ii. Economic}

Countries considered as potential new markets for Malaysia's goods and services; and

\section{iii. Humanitarian}

MTCP programmes were also carried out on humanitarian grounds like the provision of emergency relief assistance to countries facing calamities.

As always, funding was a crucial issue for any programs planned and four flexible funding modalities were employed as identified by the Economic Planning Unit (2008, pp. xv-xvi):

i. Full funding by the Malaysian Government where targeted MTCP were largely implemented using allocation under the five-year development budget (Malaysia Plan);

ii. Cost sharing between the Malaysian Government and the participating country or third parties where the recipient developing countries or third parties shared the cost of training. This funding arrangement usually applied to requests for assistance from the participating countries which were not originally included in the programme; iii. Full funding by the participating country; and iv. Full funding by third parties, e.g. donor countries and multilateral organisations. Here, the third party cooperation is not a direct activity of the MTCP. 
As mentioned earlier, the MTCP has benefitted 29,000 participants from 143 developing countries since its inception in 1981 with the total cost of USD200 million (RM880 million) for this programme. The number of MTCP participating countries started with only 35 countries in 1980. Although the MTCP was intended to strengthen regional and sub-regional cooperation, technical cooperation was not confined to the nine ASEAN member countries only. It draws interest and participation from many countries of different geographical zones, ranging from Africa, Latin America, East and Central Europe, and Oceania (see Chart 1).

\section{Chart 1: Geographical Distribution of MTCP Participants, 1980-2011}

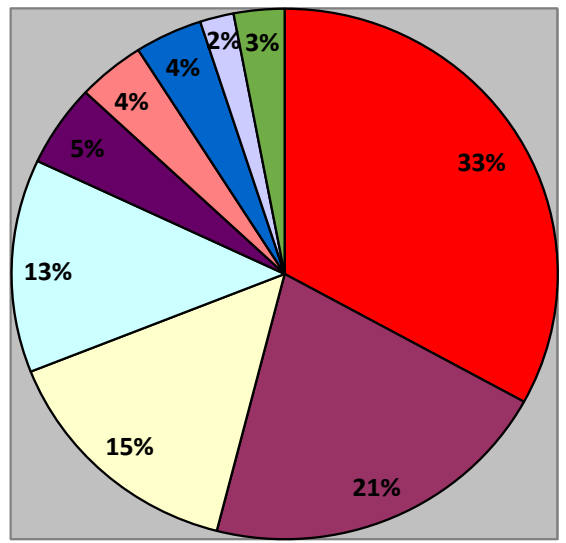

\begin{tabular}{|l|}
$\square$ ASEAN \\
$\square$ Africa \\
$\square$ North Africa \&W est Asia \\
$\square$ South Asia \\
$\square$ Pacific Island \\
$\square$ CIS \\
$\square$ Non-ASEAN Asian States \\
$\square$ East \& Central Europe \\
$\square$ Others
\end{tabular}

Source: The Malaysia Technical Cooperation Programme (2011).

As it is known, many of those receiving training in Malaysia have returned to their respective countries and have also had since been contributing their part to the development of their countries. According to Malaysia's Ministry of Foreign Affairs which administers the MTCP and the Economic Planning Unit under the Prime Minister's Department (2008, p. iii), more than one hundred and thirty countries participated in this programme between 1980/81 and 2008 at a total cost of RM408.4 million. It may be interesting to note that six out of the top ten recipient countries in 2006 were ASEAN members (see Table 1). This reflects the philosophy of 'prosper-thy-neighbour'by the Malaysian government which believes that a prosperous region will encourage a more vibrant economic cooperation between member states. Hazri and Tang (2011) also argue that the formation of the ASEAN Community has become another reason contributing to the preference of the South-East Asian countries in this programme. Furthermore, the financial allocation for the MTCP under the 
Five-Year Malaysian Development Plan has grown more than fourfold from RM45 million from 1980-1990 to RM200 million covered for the period 2006-2010 (see Table 2).

Table 1: Top Ten Recipient Countries (2006)

\begin{tabular}{|c|c|c|c|}
\hline Rank & Country & Rank & Country \\
\hline 1 & Indonesia & 6 & Sri Lanka \\
\hline 2 & Myanmar & 7 & Thailand \\
\hline 3 & Cambodia & 8 & Lao PDR \\
\hline 4 & Vietnam & 9 & Bangladesh \\
\hline 5 & Philippines & 10 & Sudan \\
\hline
\end{tabular}

Source: Economic Planning Unit (2007).

Table 2: Allocations for the MTCP, 1980-2010

\begin{tabular}{|c|c|}
\hline Year & Allocation (million ringgit) \\
\hline $1980-1985$ (RMK-4) & 45 \\
\hline $1986-1990$ (RMK-5) & 45 \\
\hline $1991-1995$ (RMK-6) & 65 \\
\hline $1996-2000$ (RMK-7) & 95 \\
\hline $2001-2005$ (RMK-8) & 160 \\
\hline $2006-2010$ (RMK-9) & 200 \\
\hline
\end{tabular}

Source: Economic Planning Unit (2007).

Table 3: Number of courses offered by the Malaysian government covered from 1980-2005.

\begin{tabular}{|c|c|}
\hline Year & Number of courses offered \\
\hline $1980-1985$ & 36 courses \\
\hline $1986-1990$ & 42 courses \\
\hline $1991-1995$ & 47 courses \\
\hline $1996-2000$ & 54 courses \\
\hline $2001-2005$ & 54 courses \\
\hline Total & 233 courses \\
\hline
\end{tabular}

Source: Source: Personal Interview, Ministry of Foreign Affairs (Malaysia) 2011. 
Table 4: Number of training institutions involved in the MTCP programs (19802005).

\begin{tabular}{|c|c|}
\hline Year & Number of training institutions \\
\hline $1980-1985$ & 10 training institutions \\
\hline $1986-1990$ & 12 training institutions \\
\hline $1991-1995$ & 15 training institutions \\
\hline $1996-2000$ & 17 training institutions \\
\hline $2001-2005$ & 34 training institutions \\
\hline Total & $\mathbf{8 8}$ training institutions \\
\hline
\end{tabular}

Source: Personal Interview, Ministry of Foreign Affairs (Malaysia) 2011.

The basis upon which the MTCP was founded was that the development of a country depends on the quality of its human resources. This is because productive people will be able to promote the socioeconomic development of a country. Perhaps for this reason, human resource training was offered in public administration, good governance, health services, education, sustainable development, agriculture and industry, energy and gas, poverty alleviation, investment promotion, information and communications technology (ICT) and banking. In all, a total of 233 courses were offered by the Malaysian government from 1980 to 2005 with 88 training institutions involved (see Table 3 for the number of courses offered by the Malaysian government covered from 19802005; see Table 4 for number of training institutions involved in the MTCP programmes from 1980-2005; and Table 5 for a partial list of activities under the MTCP in 2011). To realise its objectives, the modus operandi of the MTCP is based on the 'Five Modalities of Cooperation' which can be summarized as follows:

i. Since 1992, long-term academic courses at Masters and PhD levels were offered at five local public universities with full scholarships to qualified candidates (civil servants and students);

ii. Short-term training courses in specialised fields for less than three months were made available for public officials from developing countries. Until 2002, there were 66 scheduled courses available annually in 22 training institutions and government agencies. Indeed, Malaysia is keen to share her knowledge and experience in areas in which Malaysia has succeeded through many years of research and development such as the oil palm 
plantation management, agriculture development and management of veterinary services;

iii. Study Visits and Practical Attachment (SVPA) programmes which form the second major component of the MTCP were conducted to provide participants from requesting countries with opportunities to learn directly about Malaysian development experience through visits to and actual work assignment in Malaysian development agencies and project areas. The study visits are usually for a period of one to two weeks while attachment programmes are for a slightly longer period;

iv. Expert and Advisory Services are provided through the dispatch of qualified Malaysians to developing countries, at the request of the latter, to assist these countries in their development efforts; and

v. Project-Type and Equipment Supply (PTES) programmes incorporated the provision of Malaysian expertise, including from the private sector, into the implementation of development projects in MTCP participating countries.

\section{Special Initiatives: Third Country Technical Cooperation (TCTC)}

In order to minimise the effects of resource constraints such as specific technical expertise in implementing the programme, the MTCP vigorously collaborated with international organizations, namely the United Nations Development Programme (UNDP), the Commonwealth Fund for Technical Cooperation (CFTC), the Economic Social Commission for the Asia Pacific (ESCAP), the United Nations Industrial Development Organisations (UNIDO), Japan International Cooperation Agency (JICA), the Colombo Plan and the Asia Pacific Development for Information Programme (APDIP). For the same reason, several Malaysia's local agencies such as National Institute of Public Administration (INTAN), Institute of Diplomacy and Foreign Relations (IDFR), Universiti Putra Malaysia (UPM), Universiti Malaya (UM), the Japan Malaysia Training Institute (JMTI) and the Centre for Instructor Advanced Skills Training (CIAST) have also offered their training facilities or programmes to the recipient countries. These include technical and skills training in computer networking technology, 
welding, electrical and electronic system servicing as well as diplomacy, developing small-scale industries development and establishing a healthy environment.

Table 5: Partial list of Activities under the Malaysian Technical Cooperation Programme Training (2011)

Host Institution

Maritime Institute of Malaysia

Academy of Science Malaysia

Department of Standards Malaysia

National Institute of Public

Administration

Health Management Institute

Institute of Diplomacy and Foreign Relations

The Southeast Asia Regional Centre for Counter Terrorism International Centre for Education in Islamic Finance
International Training, Course in Strategic Management of the Maritime Sector for officials from Cambodia, Laos, Myanmar and Vietnam

Science and Technology Management Training Course for Researches in OIC Countries

Training Program on Halal Standards and Conformance Infrastructure for OIC Countries

Economic Planning And Management

Epidemiological Intelligence and
Management Programme

Diplomatic Training Course (1/2011)

Chemical Biological Radiological Nuclear Explosive (CBRNE) Threat-First Responder Action Practical Syariah Aspects in Islamic Finance

International Institute of Public Policy Managing Diversity in Multicultural
and Management $\quad$ Nations

Source: Ministry of Foreign Affairs (Malaysia) 2011.

By bringing to Malaysia 'people from the Third World countries and exposing them to projects and action plans that they could emulate', Mahathir (2007) believed, the various training programmes that Malaysia offered them could assist in enhancing their capabilities in developing their own countries. As the former Prime Minister had always reiterated, it was against his principles to go cap in hand to anyone, especially to the wealthy countries. He believed in Malaysia doing things within its capacity, and Malaysians had demonstrated their ability by themselves to develop their country and transform its economy. Mahathir explained that it is vital for the leaders of non-wealthy countries to bear 
this in mind because, he claimed, 'we need to have some pride and we must not go begging from people'.

\section{Critical Reflections}

Malaysia's major motivation to promote its international development cooperation is economic growth. Thus, the 'Malaysian Way' of providing assistance to other developing countries via its South-South Cooperation initiative is unique as the country believes in the principles of equality, mutual benefit and smart partnership among all participating nations. As can be seen, the Malaysian model for development assistance is markedly different from other conventional foreign assistance programmes which are prone to imposing donors' values and conditions on the recipient countries. In addition to that, the 'prosper-thy-neighbour' policy is also incorporated in the country's South-South Cooperation agenda and thus being the philosophical basis of Malaysia's bilateral technical cooperation programme. South-South Cooperation involved both economic and technical cooperation among developing nations aimed at complementing the development strategies of these nations through collective efforts. Indeed, as a former recipient of technical assistance as well as a rapidly emerging nation, Malaysia through its various government agencies, research and training institutions and experts with a lot of development experience and expertise to share with other developing nations. The creation of the MTCP has enabled Malaysia to share those specific experiences which showcase her strengths and expertise. Moreover, the creation of the MTCP embedded with the smart partnership policy indicated Malaysia's willingness to assist other developing nations in their efforts of developing their economies. Concomitantly, it has provided an avenue for the Malaysian government to demonstrate Malaysia's commitment to the international sphere in playing a leading role among developing countries.

Malaysia's role and contributions in the global economic development, in particular, its South-South Cooperation agenda may be small compared to any other international assistance programmes as championed by the developed nations. However, that policy thrust was not hindering its success since its inception almost 38 years ago. Successive Prime Ministers of Malaysia have assured that Malaysia will continue its technical assistance programme in the future as it has benefitted more than 29000 people from 143 developing countries all over the world. Malaysia's success in this assistance programme and being regarded as a model for growth and development by other developing nations is demonstrated by the fact that Malaysia has a track record and the experience which is more suitable to be emulated by other developing nations. In other 
words, cooperation between countries from a similar background of economic development creates a greater impact on developing nations compared to the conventional North-South cooperation. Thus, having experienced the development path Malaysia is somewhat entitled to share her experiences with other nations through the South-South Cooperation framework, specifically the MTCP.

Coherently, as far as the South-South Cooperation and the MTCP Programme are concerned, the degree or the amount of Malaysia's financial contribution may not reach billions of dollars, but considering that Malaysia itself is also a developing nation, the amount of money spent for this programme (USD200 million/RM880 million) is considered significant. Malaysia wishes to share its developmental experience with other developing nations, let alone its ASEAN neighbours, and thus promoting its 'prosper-thy-neighbour' policy. However, for the recipient countries, the amount of money invested in this program is not the issue; it reflects a political will, commitment, concern and the spirit of friendship with developing nations exhibited by the Malaysian government that counts. Moreover, as discussed earlier, it is worth it. Malaysia has gained many friends around the world thereby positioning her favourably in global politics as a champion of the developing world. This would be impossible without the support from other developing nations. This also shows how much bilateral relations with fellow nations have been strengthened and improved.

As far as the issue of sustainability of the MTCP is concerned, the issue of budget and manpower can be said as the most pressing issues as it is co-related to its survival. The increasing challenges faced by developing nations today have created new demands on the MTCP and, ultimately will result in increasing demands for the number of courses and training facilities offered and, no doubt, will cause a heavy strain on the assistance provider, in particular, the Malaysian government. A new strategic plan has to be issued concerning the MTCP's funding mechanism. Perhaps in the future, both Malaysia and those participating countries may need to co-fund the demanded training programs or through untied financial assistance from Malaysia. No doubt, Malaysia's role in South-South Cooperation, specifically the role of the MTCP in promoting cooperation among developing countries should be continued and strengthened. Finally, with the growing importance of economic and trade relations in Malaysia's foreign policy, MTCP has also been seen as an important mechanism to enhance Malaysia's economic and trade interest at the international level. 


\section{Conclusion}

To sum up, the study has demonstrated that Malaysia had a long history in championing the developing nations' interests and the country's South-South Cooperation agenda has re-enforced Malaysia's role as a strong advocate for South-South Cooperation and to promote self -reliance through development cooperation among the developing nations. For that reason, the former Prime Minister Datuk Seri Najib Razak has assured that Malaysia would continue doing so even though the country is seized with its thrust of moving towards a developed nation in 2020. Looked at in this light, and, as many observers have pointed out, whatever the future may be for Malaysia's foreign assistance programme, Malaysia has demonstrated its fair share of commitment to regional and international development within its financial capacity.

This study has demonstrated the role of an emerging donor in an attempt to provide a broader understanding of foreign aid. Malaysia, as an emerging donor provides an interesting frame of reference for foreign assistance which is usually associated with traditional donors or rich countries. Malaysia has shown its commitment towards the implementation of foreign aid to recipient countries in the developing world through the MTCP. The constructivist paradigm which is utilized as the main frame of analysis shows that the main motive behind Malaysia's foreign assistance programme was altruism as opposed to national interest. However, it can also be argued that Malaysia has also enhanced its soft power approach, especially among the developing countries.

\section{References}

Economic Planning Unit of Malaysia. <http://www.epu.gov.my/home Economic Planning Unit. (2002). The Findings of the Study on the Benefits and Impact of the MTCP. Putrajaya: Economic Planning Unit, Prime Minister's Department.

Economic Planning Unit. (2008). Malaysian Technical Cooperation Programme, MTCP: Short-Term Courses. Putrajaya: Economic Planning Unit, Prime Minister's Department.

Hazri, H., \& Tang, S.-M. (2011). Malaysian Technical Cooperation Program: Helping Friends in Need. Paper presented at the Conference on Emerging Asian Approaches to Development Cooperation, Asia Foundation, Seoul, 29 September. Retrieved from http:/asia foundation.org/publications/pdf/1011 
Institute of Strategic Management Studies (ISIS). (2011). Malaysia. In Malaysia: Policies and issues in economic development (pp. 1-38). Kuala Lumpur: Institute of Strategic Management Studies (ISIS).

Joint Study on Effective Technical Cooperation for Capacity Development: Malaysia Country Case Study. (2008). Retrieved from www.jica.go.jp/cdstudy/about/output/pdf/malaysia.pdf

Lancaster, Carol, Kwaku Nuamah, Matthew Liebe \& Todd Earl Johnson. (2006). Foreign Aid and Private Sector Development. Watson Institute for International Studies.

Mahathir Mohamad. (2011). A Doctor in the House: The Memoirs of Tun Dr Mahathir Mohamad. Petaling Jaya: MPH Group Publishing Sdn. Bhd.

Malaysian Technical Cooperation Programme Homepage.

http://mtcp.kln.gov.my/index.php

Malaysian Ministry of Foreign Affairs. http://www.kln.gov.my/web/guest/home.

New Straits Times. (1992, 23 November).

Ruggie, John, Gerard. "What makes the world hang together? Neo-utilitarianism and the social constructivist challenge." International organization 52, no. 4 (1998): 855-885.

Wendt, Alexander. "Anarchy is what states make of it: the social construction of power politics." International organization 46, no. 2 (1992): 391-425.

\section{Interview}

Personal interview with Mdm. Aslinda, 13 June 2011, at Ministry of Foreign Affairs (Malaysia). 